Yasuyoshi Sakai · Shigeru Kobayashi • Hiroki Shibata

Hiroyasu Furuumi • Toshiyasu Endo • Supan Fucharoen

Shinjiro Hamano • Gopal P. Acharya

Terukazu Kawasaki • Yasuyuki Fukumaki

\title{
Molecular analysis of $\alpha$-thalassemia in Nepal: correlation with malaria endemicity
}

Received: November 10, 1999 / Accepted: December 13, 1999

\begin{abstract}
Thalassemia is a prevalent hereditary disorder characterized by impaired synthesis of globin chains. It has been suggested that the high frequency of thalassemia might reflect heterozygote advantage due to reduced susceptibility to malaria. In Nepal, malaria has often occurred in places below the altitude of $1200 \mathrm{~m}$. We carried out a microepidemiological study on thalassemia in two neighboring populations in Nepal, the Danuwar and the Tamang. Settlements of the Danuwar are located below the limit of the malarial zone $(1200 \mathrm{~m}$ in altitude), whereas those of the Tamang are found in malaria-free uplands. Three heterozygotes for hemoglobin $(\mathrm{HbE})$ were observed in the Danuwars. We detected one type $\left(-\alpha^{3.7 I}\right)$ of $\alpha^{+}$-thalassemia that involves a deletion of $3.7 \mathrm{~kb}$, leading to a loss of one of two $\alpha$-globin genes, in the Danuwars, at a high gene frequency of $63 \%$, while the gene frequency in the Tamangs was only $5 \%$. Analysis of the $\alpha$-globin gene cluster revealed that four different haplotypes were associated with the type of $\alpha^{+}$-thalassemia in the Danuwars. Nucleotide sequences of the D-loop region in the mitochondrial DNA of the two populations indicated a similar nucleotide diversity in each
\end{abstract}

Y. Sakai $\cdot$ H. Shibata $\cdot$ H. Furuumi $\cdot$ Y. Fukumaki $(\bowtie)$

Division of Disease Genes, Institute of Genetic Information, Kyushu

University, 3-1-1 Maidashi, Higashi-ku, Fukuoka 812-8582, Japan

Tel. +81-92-642-6167; Fax +81-92-632-2375

e-mail: yfukumak@gen.kyushu-u.ac.jp

S. Kobayashi

Department of Human Geography, Graduate School of Letters,

Osaka University, Toyonaka, Japan

T. Endo

Kyushu Women's College, Kitakyushu, Japan

S. Fucharoen

Department of Clinical Chemistry, Faculty of Associated Medical Sciences, Khon Kaen University, Khon Kaen, Thailand

S. Hamano

Department of Parasitology, Faculty of Medicine, Kyushu

University, Fukuoka, Japan

G.P. Acharya

Institute of Medicine, Tribhuvan University, Kathmandu, Nepal

T. Kawasaki

Institute of Health Science, Kyushu University, Fukuoka, Japan population. The fixation index, $\mathrm{F}_{\mathrm{ST}}$, representing the degree of genetic differentiation estimated from mitochondrial DNA diversities $\left(\mathrm{F}_{\mathrm{ST}}, 0.05\right)$, was smaller than that obtained from the gene frequencies of $\alpha^{+}$thalassemia $\left(\mathrm{F}_{\mathrm{ST}}, 0.55\right)$. If we assume neutral molecular evolution in the D-loop region of mitochondrial DNA, these results suggest that the high frequency of $\alpha^{+}$thalassemia may be due to biological adaptation to the malarial environment rather than to events such as a bottleneck.

Key words Thalassemia - Globin · Genotype · Haplotype · Nepal $\cdot$ Malaria $\cdot$ Mitochondrial DNA

\section{Introduction}

Populations with a high frequency of thalassemia show different patterns of mutation, which means that the mutant alleles must have arisen independently in different parts of the world and then reached high frequency, as induced by local factors such as random genetic drift and natural selection (Weatherall 1998). Since Haldane (1949) suggested that the high frequency of thalassemia might reflect heterozygote advantage due to reduced susceptibility to malaria, a variety of studies has hinted that the selective factor might be malaria (Flint et al. 1993). However, until recent years, it has been difficult to put the hypothesis onto a solid molecular footing.

In Nepal, occurrences of malaria are frequent, especially in areas below the altitude of $1200 \mathrm{~m}$. Some populations were able to live in the malarial zone. Since 1952, the Malaria Eradication Program has reduced the prevalence of malaria; however, hereditary diseases, including thalassemia and glucose-6-phosphate dehydrogenase (G6PD) deficiency have remained and have been considered genetic factors which might have protected the populations against malaria (Modiano et al. 1991).

We carried out a microepidemiological study in two Nepalese populations, the Danuwar and the Tamang, for 
the following reasons: Although these two populations live close to each other, the Danuwars remained all day below $1200 \mathrm{~m}$, the malarial zone, while the Tamangs went down to the lowland for cultivation only during the daytime, and then went up to stay above $1200 \mathrm{~m}$, in the malaria-free region, in the evening to try to prevent malaria infection in the monsoon season (Kobayashi 1996). This suggests that the Danuwars and the Tamangs seem to have adapted to a malarial environment, biologically and culturally, respectively. To define the genetic factors involved in biological adaptation in the Danuwars, we analyzed globin genes in these two populations, and found that the frequency of $\alpha^{+}$-thalassemia exhibited a population-dependent correlation with malaria endemicity. We also analyzed mitochondrial DNA diversity within and between these two populations, as markers unlinked to the $\alpha$-globin gene. The magnitude of genetic diversity, as estimated by mitochondrial DNA sequences, was much smaller than that based on the frequency of $\alpha^{+}$-thalassemia. The high frequency of $\alpha^{+}$-thalassemia in the Danuwars is discussed in terms of biological adaptation to the malaria endemic environment.

\section{Subjects and methods}

\section{Samples}

Blood samples were collected from the two populations, the Danuwar and the Tamang, in the Kotyang area, located on a hillside about $30 \mathrm{~km}$ east of Kathmandu. The Danuwars live below the altitude of $1200 \mathrm{~m}$ in the malarial zone and the Tamangs live above $1200 \mathrm{~m}$ in the malaria-free region. According to ethnological investigations, the Danuwars were originally riparian dwellers and the Tamangs came from ancestors who migrated from higher hills, some 20odd generations ago. These two populations have not intermarried (Kobayashi 1996).

The buffy coats and red blood cells were isolated from blood samples by repeated centrifugation and washing. These samples were transported in liquid nitrogen to the laboratory in Kyushu University and stored at $-80^{\circ} \mathrm{C}$ prior to extraction. Total genomic DNAs were prepared from peripheral white blood cells, as described (Lahiri and Nurnberger 1991).

\section{Characterization of hemoglobin}

We used the method of Huisman et al. (1983), slightly modified. High performance liquid chromatography (HPLC) was done at a flow rate of $1.0 \mathrm{ml} / \mathrm{min}$ at room temperature, using a Tosoh CCP series HPLC (Tosoh, Tokyo, Japan).

Detection of the $\beta^{\mathrm{E}}$-globin gene and haplotyping of the $\beta$ globin gene cluster

The $\beta^{\mathrm{E}}$-globin gene was detected by $M n l \mathrm{I}$ digestion of polymerase chain reaction (PCR)-amplified products and by dot blot hybridization, using the allele specific oligonucleotide probes as described by Fucharoen et al. (1990). The mutation was confirmed by direct sequencing, as described by Winichagoon et al. (1992). The haplotypes at seven polymorphic sites of the $\beta$-globin gene cluster were determined by restriction enzyme analysis of the PCR-amplified products, as described elsewhere (Fukumaki and Fucharoen 1991).

Determination of $\alpha$-globin genotypes and haplotypes of the $\alpha$-globin gene cluster

Two types of $\alpha^{+}$-thalassemia mutation, the $3.7-\mathrm{kb}$ and 4.2 $\mathrm{kb}$ deletions, $-\alpha^{3.7}$ and $-\alpha^{4.2}$, respectively, were determined by PCR, using the following primers (Fig. 1):

\section{A: 5'-CCCAGAGCCAGGTTTGTTTATCTG-3' \\ B: $\quad 5^{\prime}$-GAGGCCCAAGGGGCAAGAAGCAT-3' \\ C: $\quad$ 5'-GCTAGAGCATTGGTGGTCATGCC-3' \\ D: $\quad$ 5'-TTCTGACTCTGCCCACAGCCTGA-3' \\ aG1: 5'-GCTGACCTCCAAATACCGT-3'}

aG11: 5'-CTCTGCCTCCTTGGTTAAAA-3'

PCR was carried out in a $50-\mu l$ reaction volume containing $100-250 \mathrm{ng}$ genomic DNA, $0.4 \mu \mathrm{M}$ each primer, $0.2 \mathrm{mM}$ each dNTP, $10 \%$ dimethyl sulfoxide (DMSO), $2.5 \mathrm{U}$ of KOD Dash and its PCR buffer (Toyobo, Osaka, Japan) on a GeneAmp PCR System 2400 (PE Applied Biosystems, Foster, CA, USA). The thermal conditions were as follows: initial denaturing at $94^{\circ} \mathrm{C}$ for $1 \mathrm{~min}, 30$ cycles of denaturing at $94^{\circ} \mathrm{C}$ for $30 \mathrm{~s}$, annealing at $61^{\circ} \mathrm{C}, 66^{\circ} \mathrm{C}$, and $60^{\circ} \mathrm{C}$ for $2 \mathrm{~s}$ to detect the $3.7-\mathrm{kb}$ and $4.2-\mathrm{kb}$ deletion types and the normal allele, respectively, and extension at $74^{\circ} \mathrm{C}$ for $30 \mathrm{~s}$, followed by final extension at $74^{\circ} \mathrm{C}$ for $5 \mathrm{~min}$. The $3.7-\mathrm{kb}$ deletion mutation gives rise to a specific amplification product of 1779 bp with the primers A and B (Fig. 2A). The normal 3' downstream region of the $\alpha 2$-globin gene was detected by

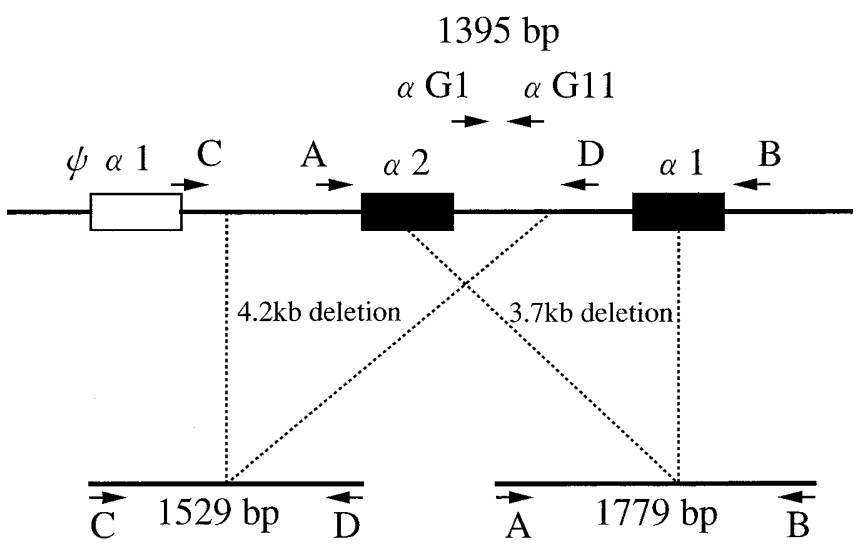

Fig. 1. The $\alpha$-globin gene cluster with specific primers used for detecting the $3.7-\mathrm{kb}$ and $4.2-\mathrm{kb}$ deletion types of $\alpha^{+}$-thalassemia. The positions of the genes are shown by the filled boxes and a pseudogene is shown by the open box. The 1779-bp and 1529-bp fragments are amplified from the $\alpha$-globin gene cluster with the $3.7-\mathrm{kb}$ and $4.2-\mathrm{kb}$ deletion, respectively, while no amplification occurs from the normal counterpart because of the long distance spanning the two sets of primers 
PCR with primers $\alpha \mathrm{G} 1$ and $\alpha \mathrm{G} 11$, generating a 1395-bp fragment (Fig. 2B).

The 3.7-kb deletion was subdivided into three groups, $-\alpha^{3.7 I},-\alpha^{3.7 I I}$, and $-\alpha^{3.7 I I I}$ depending on the location of the crossover point within the $\mathrm{Z}$ box, the homologous region of the $\alpha$-globin gene cluster. Restriction analysis with ApaI of the 1779-bp amplified fragment facilitates determination of types I, II, and III of the 3.7-kb deletion (Dode et al. 1992). The 4.2-kb deletion type yields a 1529-bp amplified fragment with primers $\mathrm{C}$ and $\mathrm{D}$.

In each population, the gene frequencies of $-\alpha^{3.7}$ and $\alpha \alpha$ were estimated by:

$\mathbf{x}_{-\alpha 3.7}=\left(2 \mathrm{n}_{-\alpha 3.7 /-\alpha 3.7}+\mathrm{n}_{\alpha \alpha /-\alpha 3.7}\right) / 2 \mathrm{n}_{\text {total }}$ and

$\mathrm{x}_{\alpha \alpha}=\left(2 \mathrm{n}_{\alpha \alpha / \alpha \alpha}+\mathrm{n}_{\alpha \alpha /-\alpha .7}\right) / 2 \mathrm{n}_{\text {total }}$, respectively.

In these formulas, $\mathrm{n}$ means number of individuals with genotypes indicated as subscripts.

The heterozygosity within the two populations was estimated by:

$\mathrm{H}_{\mathrm{w}}=\mathrm{x}_{-\alpha 3.7 \text { Danuwars }} \cdot \mathbf{x}_{\alpha \alpha \text { Danuwars }}+\mathbf{x}_{-\alpha 3.7 \text { Tamangs }} \cdot \mathbf{x}_{\alpha \alpha \text { Tamangs }} \cdot$

The heterozygosity between the two populations was estimated by:

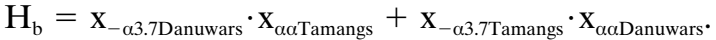

The fixation index was estimated using the formula:

$\mathrm{F}_{\mathrm{ST}}=1-\mathrm{H}_{\mathrm{w}} / \mathrm{H}_{\mathrm{b}}$ (Hudson et al. 1992).

The haplotypes were determined by restriction enzyme analysis of PCR-amplified products at eight polymorphic sites of the $\alpha$-globin gene cluster (Martinson et al. 1994; Higgs et al. 1986).

Sequencing of mitochondrial DNA and quantifying the nucleotide diversity

A 740-bp fragment from the D-loop region of mitochondrial DNA was amplified by PCR from total genomic DNAs (100-250ng), using the following primers (Horai et al. 1996):

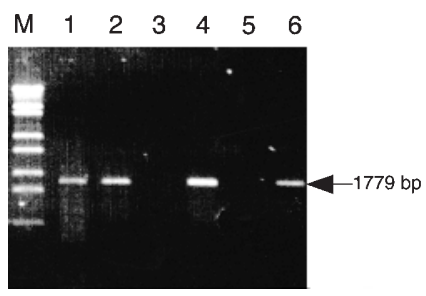

A

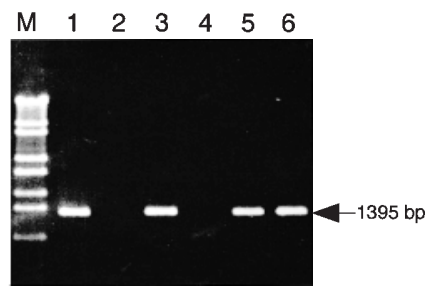

B
Fig. 2A,B. Polymerase chain reaction analysis detecting $\alpha^{+}$-thalas semia. A The 1779-bp fragment was amplified from the 3.7-kb deletion allele $\left(-\alpha^{3.7}\right)$ with primers A and B. B The 1395-bp fragment was amplified from the normal allele $(\alpha \alpha)$ with primers $\alpha \mathrm{G} 1$ and $\alpha \mathrm{G} 11$. The genotypes of the specimens in lanes 2 and 4 are diagnosed as $-\alpha^{3.7}$ $-\alpha^{3.7}$, in lanes 1 and 6 as $\alpha \alpha /-\alpha^{3.7}$, and in lanes 3 and 5 as $\alpha \alpha / \alpha \alpha . M$ is StyI-digested $\lambda$ DNA as size reference. See text for details of primers
Forward primer: 5'-AAACTATTCTCTGTTCTTTC-3' (16011-16030)

Reverse primer: 5'-TAATATTGAACGTAGGTGCG-3' (181-162).

Numbering of bases is according to the notation of Anderson et al. (1981). The PCR conditions were the same as those for $\alpha$-globin genotyping, except for primers and the annealing temperature, $45^{\circ} \mathrm{C}$. Cycle sequencing of the DNA fragments was done in a $10-\mu 1$ reaction volume, containing 100-300ng PCR-amplified DNA and $1 \mu \mathrm{M}$ forward or reverse primer, with a BigDye Terminator Cycle Sequencing Ready Reaction Kit (PE Applied Biosystems, Foster, CA, USA), using a GeneAmp PCR System 2400. The sequences were analyzed on a Model ABI PRISM 377 DNA Sequencer (PE Applied Biosystems).

Nucleotide sequences of a 478-bp region ranging from positions 16092 to 16569 were analyzed using DnaSP version 2.52 software (Rozas and Rozas 1997) to calculate the nucleotide diversity and the fixation index $\left(\mathrm{F}_{\mathrm{ST}}\right)$ between the two populations (Hudson et al. 1992).

\section{Results}

Hemoglobin $(\mathrm{Hb})$ analysis and identification of the $\beta^{\mathrm{E}}$ mutation

On HPLC analysis, as one abnormal $\mathrm{Hb}$ peak was observed at the position of $\mathrm{HbA}_{2}$ in three samples of the Danuwars, this peak was perhaps due to $\mathrm{HbE}$. Restriction analysis of PCR-amplified products with $M n l I$ showed that these three individuals were heterozygous for the $\beta^{\mathrm{E}}$ mutation (data not shown). This was also confirmed by dot blot hybridization with allele-specific oligonucleotide probes (Fig. 3) and direct sequencing of PCR-amplified products (data not shown). Haplotypes of the $\beta$-globin gene cluster associated with the $\beta^{\mathrm{E}}$ mutation were determined by a PCR-based method (Fukumaki and Fucharoen 1991). The haplotype of the $\beta$-globin gene cluster linked to the $\beta^{\mathrm{E}}$ mutation was as follows: presence $(+)$ or absence $(-)$ of the HincII site $5^{\prime}$ to the $\varepsilon$-globin gene, the HindIII sites of the ${ }^{\mathrm{G}} \gamma$ and ${ }^{\mathrm{A}} \gamma$-globin genes, the HincII sites within and $3^{\prime}$ to the $\psi \beta 1$-globin gene, the AvaII site of the $\beta$-globin gene, the BamHI site $3^{\prime}$ to the $\beta$-globin gene were,,,,,,+----+- , respectively.

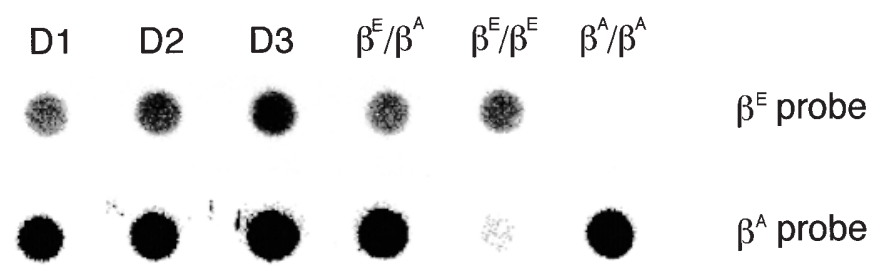

Fig. 3. Detection of the $\beta^{\mathrm{E}}$ mutation by dot blot hybridization with allele-specific oligonucleotide probes. Samples D1, D2, and D3 were derived from the Danuwars with abnormal hemoglobin ( $\mathrm{Hb})$. Samples $\beta^{\mathrm{E}} / \beta^{\mathrm{A}}, \beta^{\mathrm{E}} / \beta^{\mathrm{E}}$, and $\beta^{\mathrm{A}} / \beta^{\mathrm{A}}$ were derived from a heterozygote, a homozygote for the $\beta^{\mathrm{E}}$ mutation, and a normal individual, respectively 
Determination of $\alpha$-globin genotypes and haplotypes of the $\alpha$-globin gene cluster

We determined the $\alpha$-globin genotypes of 110 Danuwars and 114 Tamangs in the Kotyang area, by PCR using the primers shown in Fig. 1. This enabled detection of either the $3.7-\mathrm{kb}$ or $4.2-\mathrm{kb}$ deletion types of $\alpha^{+}$-thalassemia. The results are summarized in Table 1 . The $3.7-\mathrm{kb}$ deletion type $\left(-\alpha^{3.7}\right)$ was detected at a high frequency $(0.63)$ in the Danuwars, while the deletion was less frequent (0.05) in the Tamangs. $\mathrm{H}_{\mathrm{w}}$ and $\mathrm{H}_{\mathrm{b}}$, measuring heterozygosity within and between populations, respectively, were 0.28 and $0.62 . \mathrm{F}_{\mathrm{ST}}$ was 0.55 . The $3.7-\mathrm{kb}$ deletion type found in these two populations proved to be type I $\left(-\alpha^{3.7 I}\right)$ based on restriction analysis with $A p a \mathrm{I}$. The 4.2-kb deletion type was not found in either population.

We determined the $\alpha$-globin haplotypes of 44 alleles in the Danuwars and 9 alleles in the Tamangs, based on results of family studies. Four different haplotypes, Ia, Ib, IIa, and IIc were associated with the $3.7-\mathrm{kb}$ deletion allele of the Danuwars (Table 2).

Nucleotide diversity analysis of the D-loop region in mitochondrial DNA

We sequenced the D-loop region of mitochondrial DNA of both populations. Sequence comparison of 109 Danuwars and 71 Tamangs with the previously published mitochondrial genomic sequence (Anderson et al. 1981) showed 37 different mitochondrial DNA sequences. Thirty-two and 37 polymorphic sites were observed in the Danuwars and the Tamangs, respectively. The range of nucleotide diversity $(\pi)$ within the Danuwars and the Tamangs was esti- mated to be $0.010 \pm 0.5 \times 10^{-4}$ and $0.012 \pm 0.7 \times 10^{-4}$, respectively. $\mathrm{F}_{\mathrm{ST}}$ was calculated to be 0.050 .

\section{Discussion}

In the two Nepalese populations, we noted that the frequency of $\alpha^{+}$-thalassemia (0.63) in the Danuwars was much higher than that $(0.05)$ in the Tamangs, which indicates that these frequencies exhibited an altitude-dependent correlation with malaria endemicity. We also analyzed the mitochondrial DNA diversity of each population as markers unlinked to the $\alpha$-globin gene cluster. These two populations had a similar nucleotide diversity of mitochondrial DNA. Based on these data, we calculated the fixation index $\left(\mathrm{F}_{\mathrm{ST}}\right)$ to measure the degree of genetic differentiation between these populations. Considering that the population size of mitochondrial DNA is roughly one-fourth that of chromosomal DNA, it is expected that the $\mathrm{F}_{\mathrm{ST}}$ should be larger when estimated from mitochondrial DNA diversity than that from gene frequencies of chromosomal DNA. However, between the Danuwars and the Tamangs, $\mathrm{F}_{\mathrm{ST}}$ was smaller $\left(\mathrm{F}_{\mathrm{ST}}=0.05\right)$ when estimated from the mitochondrial DNA data than when estimated from the $\alpha$-globin gene data $\left(\mathrm{F}_{\mathrm{ST}}=0.55\right)$. We also found that four different haplotypes of the $\alpha$-globin gene cluster were linked to the $3.7-\mathrm{kb}$ deletion allele in the Danuwars. These results support the notion that the high frequency of $\alpha^{+}$-thalassemia was due to locally acting factors rather than to founder or bottleneck effects.

Since Haldane (1949) suggested that the high frequency of thalassemia had resulted from malarial selection, a variety of studies has supported the hypothesis. Much data have

Table 1. Frequencies of $\alpha$-thalassemia in Danuwars and Tamangs

\begin{tabular}{llllllll}
\hline & & Total & $-\alpha^{3.7} /-\alpha^{3.7}$ & $\alpha \alpha /-\alpha^{3.7}$ & $\alpha \alpha / \alpha \alpha$ & $-\alpha^{3.7}$ & $\alpha \alpha$ \\
\hline \multirow{2}{*}{ Danuwars } & Number & \multirow{2}{*}{110} & 41 & 57 & 12 & & \\
\multirow{2}{*}{ Tamangs } & Frequency & & 0.37 & 0.52 & 0.11 & 0.63 & 0.37 \\
& Number & \multirow{2}{*}{114} & 1 & 9 & 0.04 & & \\
& Frequency & & 0.01 & 0.08 & 0.91 & 0.05 & 0.95 \\
\hline
\end{tabular}

Table 2. Haplotypes of the $\alpha$-globin gene cluster of Danuwars and Tamangs

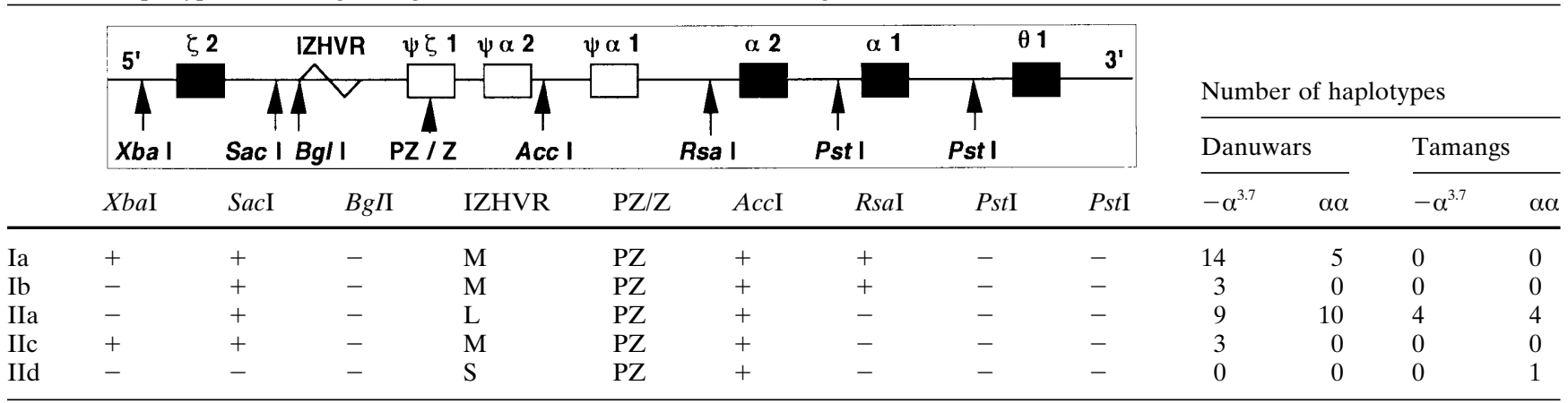

The positions of genes are shown by filled boxes and pseudogenes are shown by open boxes

IZHVR, Inter- $\zeta$ hypervariable region; S,M, and L, small, medium, and large IZHVR allele sizes, respectively; PZ/Z, $\psi \zeta$ pseudogene / $\zeta$-gene 
come from studies of $\alpha$-thalassemia in Melanesia and Polynesia. Flint et al. (1986) showed that $\alpha^{+}$-thalassemia had a gene frequency proportional to the prevalence of malaria in the southwest Pacific region. They carried out a microepidemiological study in wide areas, including various heterogeneous populations, and have shown that three different $\alpha$-globin gene deletions, $-\alpha^{4.2},-\alpha^{3.71}$, and $-\alpha^{3.7 I I I}$, contributed to the high frequency of $\alpha^{+}$-thalassemia. In our study, we specified two populations investigated ethnologically and we noted a clear genetic difference of $-\alpha^{3.71}$ gene frequency between these two populations.

In the Nepalese, $\mathrm{HbH}, \mathrm{HbE}$, and $\beta$-thalassemia have been detected only sporadically (Brain and Vella 1958, Adams 1974, Weatherall and Vella 1960, Jackson et al. 1960). We found three heterozygotes for $\mathrm{HbE}$ in this study. The same haplotype of the $\beta$-globin gene cluster harboring this mutation in the Danuwars was also found in Southeast Asians with $\mathrm{HbE}$. $\mathrm{HbE}$ is prevalent in Southeast Asian countries, especially in Thailand. The prevalence of $\mathrm{HbE}$ is $13 \%$ on average in Thailand and as high as $70 \%$ in the northeast of that country (Fucharoen and Winichagoon 1987). HbE may have advantages against malaria infection, although no inhibitory effect of erythrocytes from persons with $\mathrm{HbE}$ on malaria parasite development was observed in an in-vitro culture system of Plasmodium falciparum (Santiyanont and Wilairat 1981). However, we cannot conclude that $\mathrm{HbE}$ is selective for malaria in the Danuwars, as the frequency was low (0.014).

Since 1981, serial investigations of a lowland population, the Tharu, have been carried out in southern Nepal. These studies showed decreased malaria morbidity in the population, which showed $\beta$-thalassemia, sickle-cell anemia, and glucose-6-phosphate dehydrogenase (G6PD) deficiency with a low frequency (Morpurgo et al. 1981). Subsequently, these studies revealed that the population had a high frequency of $\alpha^{+}$-thalassemia, which was almost exclusively accounted for by the $-\alpha^{3.71}$ deletion; the gene frequency reached 0.83 (Modiano et al. 1991). The sample size in their study of $\alpha$-thalassemia genotyping is relatively small, less than 20 for each population, and there is the possibility of a bottleneck effect on high frequency of $\alpha^{+}$thalassemia in populations. We determined the genotypes of more than 100 individuals for each population in central Nepal and also examined the nucleotide diversity of mitochondrial DNA to exclude the possibility of the involvement of a random genetic drift in the predominance of $\alpha^{+}$-thalassemia.

The biochemical evidence for resistance to malaria due to thalassemia is controversial. Several investigators have reported that thalassemic erythrocytes may be less susceptible than normal cells to malaria infection in an in-vitro culture system of Plasmodium falciparum (Friedman 1979; Ifediba et al. 1985; Brockelman et al. 1987), whereas reports not in agreement with these observations are also available (Pasvol and Wilson 1982; Modiano et al. 1991). Williams et al. (1996) reported that young children homozygous for $\alpha^{+}$thalassemia in Vanuatu had a higher frequency of malaria in the first 2 years of life, after which this effect was not seen; they suggested that $\alpha^{+}$-thalassemia may have been selected for the potential to increase susceptibility to Plasmodium vivax, which functioned as a natural vaccine against subsequent severe Plasmodium falciparum malaria. Allen et al. (1997) carried out a casecontrol study in north Papua New Guinea and showed that $\alpha^{+}$-thalassemia protected children against malaria and other infections. It will be of interest to determine if that is also the case for the Nepalese population we studied.

In the Danuwars, haplotypes, Ia, Ib, IIa, and IIc were linked to the 3.7-kb deletion allele, and two of the, haplotypes Ia and IIa, were also linked to the normal allele. Association of haplotypes Ia and IIa with both normal and 3.7-kb deletion alleles was also noted in Southeast Asian populations (Higgs et al. 1989), suggesting that these populations share the same origin of the $3.7-\mathrm{kb}$ deletion. This speculation was prompted by the finding that the haplotype of the $\beta$-globin gene cluster harboring the $\beta^{\mathrm{E}}$-globin gene in a family of the Danuwars corresponded to that previously found in Southeast Asian populations (Fucharoen et al. 1990). These observations suggest a close genetic relationship between the Nepalese and Southeast Asian populations.

Acknowledgments We are grateful to Professor Hajime Nawata (Kyushu University) for his hospitality, to Professor Satoshi Umemura and Dr. Tomoaki Ishigami (Yokohama City University) for providing some of the samples studied here, and to Professor Tetsuro Ogaki, Professor Kenjiro Kawashima, Dr. Hiroshi Ishii (Kyushu University) and Professor Kazue Itoh (Nakamura Gakuen University), Dr. Sashi Sharma, Dr. Sanu Bhai Khadka (Tribhuvan University), Dr. Prabhat Baral (Nepal Medical College), Mr. Ram B. Rai, Mr. Harka B. Rai and Mr. and Mrs. Krishna B. Tamang for their excellent cooperation in the fieldwork. We are also grateful to Professor John B. Clegg (University of Oxford) for advice on the $\alpha$-globin haplotyping, and to Professor Hidenori Tachita and Mr. Hitoshi Araki (Kyushu University) for pertinent advice on analysis based on population genetics.

This research was supported in part by Grants from the Ministry of Education, Science and Culture of Japan (nos. 08041178 and 09041186) to T.K. and (nos. 10115211 and 11112215 to Y.F).

\section{References}

Adams WH (1974) A survey for hemoglobinopathies in Nepal. Trans R Soc Trop Med Hyg 68:392-396

Allen SJ, O'Donnell A, Alexander NDE, Alpers MP, Peto TEA, Clegg JB, Weatherall DJ (1997) $\alpha^{+}$-Thalassemia protects children against disease caused by other infections as well as malaria. Proc Natl Acad Sci USA 94:14736-14741

Anderson S, Bankier AT, Barrell BG, de Bruijn MHL, Coulson AR, Drouin J, Eperon IC, Nierlich DP, Roe BA, Sanger F, Schreier PH, Smith AJH, Staden R, Young IG (1981) Sequence and organization of the human mitochondrial genome. Nature 290:457-465

Brain MC, Vella F (1958) Haemoglobin-H trait in a Nepalese Gurkha woman. Lancet 7013 (vol 1 for 1958):192-194

Brockelman CR, Wongsattayanont B, Tan-ariya P, Fucharoen S (1987) Thalassemic erythrocytes inhibit in vitro growth of Plasmodium falciparum. J Clin Microbiol 25:56-60

Dodé C, Krishnamoorthy R, Lamb J, Rochette J (1992) Rapid analysis of $-\alpha^{3.7}$ thalassaemia and $\alpha \alpha \alpha^{\text {anti3.7 }}$ triplication by enzymatic amplification analysis. Br J Haematol 82:105-111

Flint J, Harding RM, Boyce AJ, Clegg JB (1993) The population genetics of the haemoglobinopathies. Clin Haematol 6:215-262

Flint J, Hill AVS, Boeden DK, Oppenheimer SJ, Sill PR, Serjeantson SW, Bana-Koiri J, Bhatia K, Alpers MP, Boyce AJ, Weatherall DJ, Clegg JB (1986) High frequencies of $\alpha$-thalassemia are the result of natural selection by malaria. Nature 321:744-750 
Friedman MJ (1979) Oxidant damage mediates variant red cell resistance to malaria. Nature 280:245-247

Fucharoen G, Fucharoen S, Jetsrisuparb A, Fukumaki Y (1990) Molecular basis of HbE- $\beta$-thalassemia and the origin of $\mathrm{HbE}$ in northeast Thailand: identification of one novel mutation using amplified DNA from buffy coat specimens. Biochem Biophys Res Commun 170:698-704

Fucharoen S, Winichagoon P (1987) Hemoglobinopathies in Southeast Asia. Hemoglobin 11:65-88

Fukumaki Y, Fucharoen S (1991) Generation and spread of globin gene mutations in populations: $\beta$-thalassemia in Asian countries. In: Kimura M, Takahata N (eds) New aspects of the genetics of molecular evolution. Japan Scientific Societies Press, Tokyo, pp 153-176

Haldane JBS (1949) The rate of mutation of human genes. In: Proceedings of the VIII International Congress of Genetics and Heredity. Hereditas (Suppl. 35):267-273

Higgs DR, Wainscoat JS, Flint J, Hill AVS, Thein SL, Nicholls RD, Teal H, Ayyub H, Peto TEA, Falusi AG, Jarman AP, Clegg JB, Weatherall DJ (1986) Analysis of the human $\alpha$-globin gene cluster reveals a highly informative genetic locus. Proc Natl Acad Sci USA 83:5165-5169

Higgs DR, Vickers MA, Wilkie AOM, Pretorius I-M, Jarman AP, Weatherall DJ (1989) A review of the molecular genetics of the human $\alpha$-globin gene cluster. Blood 73:1081-1104

Horai S, Murayama K, Hayasaka K, Matsubayashi S, Hattori Y, Fucharoen G, Harihara S, Park KS, Omoto K, Pan I-H (1996) mtDNA polymorphism in East Asian populations, with special reference to the peopling of Japan. Am J Hum Genet 59:579-590

Hudson RR, Slatkin M, Maddison WP (1992) Estimation of levels of gene flow from DNA sequence data. Genetics 132:583-589

Huisman THJ, Henson JB, Wilson JB (1983) A new high-performance liquid chromatographic procedure to quantitate hemoglobin A1c and other minor hemoglobins in blood of normal, diabetic, and alcoholic individuals. J Lab Clin Med 102:163-173

Ifediba TC, Stern A, Ibrahim A, Rieder RF (1985) Plasmodium falciparum in vitro: diminished growth in hemoglobin $\mathrm{H}$ disease erythrocytes. Blood 65:452-455

Jackson FS, Lehmann H, Sharih A (1960) Thalassemia in a Tibetan discovered during a haemoglobin survey among the Sherpas. Nature
188:1121-1122

Kobayashi S (1996) Cultural and biological adaptations to malaria in Nepal. Bull Graduate School of Social and Cultural Studies, Kyushu University 2:59-73

Lahiri DK, Nurnberger JI Jr (1991) A rapid non-enzymatic method for the preparation of HMW DNA from blood for RFLP studies. Nucleic Acids Res 19:5444

Martinson JJ, Boyce AJ, Clegg JB (1994) VNTR alleles associated with the $\alpha$-globin locus are haplotype and population related. Am J Hum Genet 55:513-525

Modiano G, Morpurgo G, Terrenato L, Novelletto A, Di Rienzo A, Colombo B, Purpura M, Mariani M, Santachiara-Benerecetti S, Brega A, Dixit KA, Shrestha SL, Lania A, Wanachiwanawin W, Luzzatto L (1991) Protection against malaria morbidity: nearfixation of the $\alpha$-thalassemia gene in a nepalese population. Am J Hum Genet 48:390-397

Morpurgo G, Modiano G, Santachiara-Benerecetti S (1981) Researches on the biology of Himalayan populations. Acta Anthropogenetica 5:235-254

Pasvol G, Wilson RJ (1982) The interaction of malaria parasites with red blood cells. Br Med Bull 38:133-140

Rozas J, Rozas R (1997) DnaSP version 2.0: a novel software package for extensive molecular population genetics analysis. Comput Appl Biosci 13:307-311

Santiyanont R, Wilairat P (1981) Red cells containing hemoglobin E do not inhibit malaria parasite development in vitro. Am J Trop Med Hyg 30:541-543

Weatherall DJ (1998) Thalassemia in the next millennium. Ann New York Acad Sci 850:1-9

Weatherall DJ, Vella F (1960) Thalassemia in a Gurkha family. BMJ 5187:1711-1713

Williams TN, Maitland K, Bennett S, Ganczakowski M, Peto TEA, Newbold CI, Bowden DK, Weatherall DJ, Clegg JB (1996) High incidence of malaria in $\alpha$-thalassaemic children. Nature 383:522-525

Winichagoon P, Fucharoen S, Wilairat P, Chihara K, Fukumaki Y, Wasi P (1992) Identification of five rare mutations including a novel frameshift mutation causing $\beta^{0}$-thalassemia in Thai patients with $\beta^{0}$-thalassemia/hemoglobin E disease. Biochim Biophys Acta 1139: $280-286$ 